\title{
Hormon Tiroid pada Kondisi Anak dengan Sepsis
}

\author{
Bambang, Asri Purwanti M. Supriatna TS \\ Departemen Ilmu Kesehatan Anak Fakultas Kedokteran Universitas Diponegoro/RSUP dr. Kariadi, \\ Semarang
}

\begin{abstract}
Latar belakang. Hormon tiroid mempunyai peranan penting dalam penyesuaian fungsi metabolik. Selama sepsis terjadi eutyroid sick syndrome melalui mekanisme disfungsi neuroendokrin pada aksis hypothalamuspituitary-thyroid yang ditandai dengan kadar T3 rendah.

Tujuan. Mendeskripsikan kadar hormon tiroid pada kondisi anak dengan sepsis

Metode. Desain studi observasional subyek penelitian adalah penderita sepsis yang dirawat di HCU dan PICU Departemen Ilmu Kesehatan Anak RSUP Dr. Kariadi Semarang pada tahun 2012 yang memenuhi kriteria inklusi. Diagnosis sepsis berdasarkan kriteria Internasional Consensus Conference on Pediatric Sepsis tahun 2005. Analisis statistik dengan uji Fisher exact dan Pearson chi square

Hasil. Subjek 30 anak terdiri dari 20 laki-laki dan 10 perempuan, 18 dengan kultur positif dan 12 negatif. Median kadar T3 1,2 (0,6-6,35) ๆg/dl T4 $9.74(4,44-16,22) \mu \mathrm{g} / \mathrm{dl}$ dan kadar TSH 1,65 ( 0.05 - 15,19) $\mu \mathrm{U} / \mathrm{dl}$. Perbedaan antara kadar T3 dan luaran ditunjukkan dengan $\mathrm{p}=1,00$. Perbedaan antar T4 dan luaran ditunjukan dengan $\mathrm{p}=0,30$. Perbedaan antara kadar TSH dan luaran $\mathrm{p}=0,44$. Pada analisis subgroup, kondisi sepsis pada kadar T3 dan TSH rendah dibandingkan penderita dengan kadar T3 rendah maupun kadar TSH normal atau meningkat ( $\mathrm{p}=0,049 ; \mathrm{OR}=.156 \mathrm{IK}=0,025-0,974)$.

Kesimpulan. Tidak terdapat perbedaan yang bermakna kadar hormon tiroid pada penderita sepsis dengan luaran perbaikan perburukan. Sari Pediatri 2014;16(1):97-102.
\end{abstract}

Kata kunci: sepsis, hormon tiroid, T3,T4, TSH

epsis adalah penyakit sistemik yang disebabkan oleh penyebaran mikroba atau toksin ke dalam aliran darah dan menimbulkan respons sistemik. Sepsis juga merupakan kedaruratan medik yang

Alamat korespondensi:

Dr. Bambang, SpA. RSUD Seruyan. Jl. A. Yani No. 30 Kuala Pembuang, Seruyan, Kalimantan Tengah 74212. Email: bbgdoank@idai.or.id, bbgdoank@gmail.com memerlukan pengobatan segera untuk menurunkan angka kematian. ${ }^{1-5}$ Sepsis dapat terjadi pada pasien dengan kondisi kritis dan angka kematiannya tinggi terutama di negara yang sedang berkembang. ${ }^{6,7}$

Insiden sepsis pada anak 1-10 per 1000 kelahiran hidup dengan mortalitas 13\%-50\%. Di Amerika Serikat, sepsis merupakan penyebab kematian urutan ke-13 pada anak yang berumur di atas 1 tahun dan dalam satu tahun dijumpai 500.000-750.000 kasus dan 50\%$70 \%$ dilaporkan bertahan hidup. ${ }^{5,7}$ Di Indonesia, angka 
kematian karena sepsis masih sangat tinggi (50\%-70\%) dan apabila terjadi syok septik serta disfungsi organ multipel kematian meningkat $(80 \%){ }^{8}$

Hormon tiroid memegang peranan penting pada adaptasi fungsi metabolisme selama stress dan sakit kritis. Kondisi ini secara terminologi disebut Euthyroid Sick Syndrome yang mempunyai karakteristik kadar T3 dalam serum menurun sedangkan Thyroxine (T4) dan TSH meningkat sedikit. Ternyata, rendahnya kadar T3 ini disebabkan oleh penurunan konversi T4 menjadi T3 di perifer." 10 Selanjutnya, kadar dan TSH dalam sirkulasi sering kali kembali ke normal sementara T3 tetap rendah. Walaupun rerata kadar serum TSH tidak berbeda bermakna dengan kadar normal, peningkatan kadar TSH nokturnal tidak ditemukan. Besarnya penurunan T3 selama periode 24 jam terbukti menggambarkan berat ringannya penyakit. ${ }^{11}$

Dalam konteks ini, penanda endokrin termasuk serum kortisol tinggi dan atau kadar T3 rendah (low T3 syndroma) mempunyai korelasi luaran yang buruk pada pasien sakit kritis pada anak dengan sepsis meningokokus yang meninggal. ${ }^{12}$

Pada penelitian sepsis meningokokus anak, Joosten $\mathrm{dkk}^{13}$ mengamati respon metobolik dan hormonal di antara penderita yang survivor dan non survivor. Pada sepsis ini, perubahan sistem endokrin sebagian besar dipengaruhi respon spesifik dari tubuh dan dimediatori sebagian besar oleh sitokin dan enzim. Didapatkan perbedaan penurunan kadar T3 dan T4 dan peningkatan kadar rT3, kadar fT4 normal dan peningkatan kadar TSH, tetapi bukan mekanisme kompensasi. ${ }^{14}$ Penelitian Angelousi dkk, ${ }^{15}$ menyimpulkan perubahan hormon tiroid pada fase akut mendukung keluaran yang buruk pada pasien sepsis.

Tujuan penelitian ini untuk mengetahui kadar hormon tiroid pada kondisi anak sepsis dan apakah terdapat perbedaan kadar hormon tiroid pada berbagai kondisi anak sepsis.

\section{Metode}

Penelitian rancangan studi observasional pada anak dengan sepsis. Penelitian dilakukan di RSUP Dr. Kariadi selama bulan September 2012 sampai dengan Februari 2013. Izin penelitian didapatkan dari Komite Etik Penelitian Kesehatan Fakultas Kedokteran Universitas Diponegoro / RSUP Dr. Kariadi Semarang dengan Ethical Clearance No.352/ EC/FK/RSDK/2012.
Persetujuan untuk diikutsertakan dalam penelitian dimintakan dari orang tua penderita secara tertulis dengan menggunakan informed consent.

Pengambilan sampel dilakukan secara konsekutif dengan jumlah 30 subyek, dengan kriteria inklusi anak dengan sepsis berusia 1 bulan - 14 tahun, dirawat di PICU dan HCU, tidak menderita HIV/ AIDS, gizi buruk, tidak hipertiroid, hipotiroid, dan kelainan kongenital. Subyek diekslusi apabila orang tua menolak ikut dalam penelitian ini.

Subyek yang telah memenuhi kriteria inklusi dan eksklusi dilakukan pengambilan darah dari vena dan dilakukan pemisahan serum. Selanjutnya, digunakan untuk pemeriksaan kadar T3, T4 dan TSH dengan metode ELISA. Uji Fisher exact dan uji Pearson chi-square dilakukan untuk mencari perbedaan kadar hormon tiroid pada berbagai kondisi anak dengan sepsis.

\section{Hasil}

Didapatkan 30 subyek penelitian yang sesuai dengan kriteria penelitian. Karakteristik demografis subyek penelitian tertera pada Tabel 1 .

Tabel 1 menunjukkan karakteristik demografi, sebagian besar adalah laki-laki 20 (67\%) anak. Rerata umur 41,7 bulan dengan umur termuda 2 bulan dan tertua 144 bulan. Dari status gizi sebagian besar subyek penelitian termasuk gizi baik (67\%).

Karakteristik diagnosis subyek saat dirawat tertera pada Gambar 1. Data pada Gambar 1 menunjukkan sebagian besar subyek adalah kelompok non bedah, diagnosis terbanyak bronkhopneumonia (20\%) dan meningoensefalitis (20\%), selanjutnya post laparatomi, pasca status konvulsivus, dan DADB masing-masing 7\%.

Tabel 2 menunjukkan median kadar T3 1,2 (0,6$6,35) \eta \mathrm{g} / \mathrm{dl}$ T4 9,74 $(4,44-16,22) \mu \mathrm{g} / \mathrm{dl}$, dan TSH $1,65(0,05-15,19) \mu \mathrm{U} / \mathrm{dl}$.

Dari tabel 3 diketahui tidak ada perbedaan kadar hormon tiroid pada 2 kelompok kondisi sepsis. Didapatkan variabel perancu, status gizi, dan penyakit dasar. Variabel perancu tidak signifikan memengaruhi luaran sepsis pada anak.

Kadar TSH yang rendah terhadap luaran pada kedua kelompok pada anak sepsis terdapat perbedaaan bermakna dengan RR 0,156 (IK 0,025 - 0,974) $\mathrm{p}=0,049$. Apabila didapatkan kadar TSH rendah maka akan terjadi perburukan 0,156 kali dibandingkan kadar TSH yang normal dan atau tinggi. 


\section{Pembahasan}

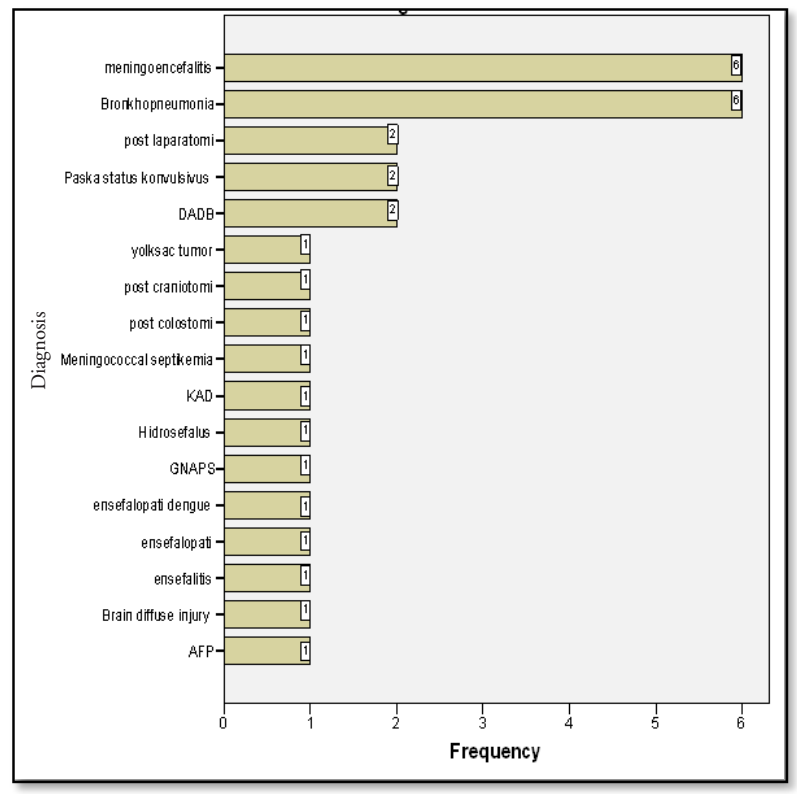

Gambar 1. Diagnosis masuk subyek
Hormon tiroid memainkan peran penting dalam adaptasi fungsi metabolisme terhadap stress dan penyakit kritis seperti sepsis dan syok sepsis. Hal ini di buktikan setelah penyakit sistemik yang diderita sembuh maka tes kelainan fungsi kelenjar tiroid juga

Tabel 1. Karakteristik subyek penelitian

\begin{tabular}{lcc}
\hline Karakteristik & $\mathrm{n}(\%)$ & Rerata \pm SD \\
\hline Jenis kelamin & & \\
Laki-laki & $20(67)$ & \\
Perempuan & $10(33)$ & \\
Umur ( bulan ) & & $41,7 \pm 42,07$ \\
Status gizi & & \\
Baik & $20(67)$ & \\
Kurang & $10(33)$ & \\
Penyakit dasar & $23(77)$ \\
Non bedah & $7(23)$ \\
Bedah &
\end{tabular}

Tabel 2. Berbagai nilai tengah kadar hormon tiroid

\begin{tabular}{lccccc}
\hline Variabel & Rerata & SB & Median & Minimum & Maksimum \\
\hline T3 & 1,46 & 1,0 & 1,21 & 0,60 & 6,35 \\
T4 & 10,29 & 3,2 & 9,74 & 4,44 & 16,22 \\
TSH & 2,80 & 3,3 & 1,65 & 0,05 & 15,19 \\
\hline
\end{tabular}

Tabel 3. Perbedaan antara kadar hormon tiroid dan kondisi anak dengan sepsis

\begin{tabular}{|c|c|c|c|c|c|}
\hline & \multicolumn{2}{|c|}{ Perbaikan } & \multicolumn{2}{|c|}{ Perburukan } & \multirow{2}{*}{$\mathrm{p}$} \\
\hline & $\mathrm{n}$ & $\%$ & $\mathrm{n}$ & $\%$ & \\
\hline \multicolumn{6}{|l|}{ T3 } \\
\hline Rendah & 20 & 95 & 8 & 89 & \multirow{3}{*}{$1,00^{*}$} \\
\hline Normal/tinggi & 1 & 5 & 1 & 11 & \\
\hline Total & 21 & 100 & 9 & 100 & \\
\hline \multicolumn{6}{|l|}{$\mathrm{T} 4$} \\
\hline Rendah & 1 & 5 & 1 & 11 & \multirow{3}{*}{$0,30^{*}$} \\
\hline Normal/tinggi & 20 & 95 & 8 & 89 & \\
\hline Total & 21 & 100 & 9 & 100 & \\
\hline \multicolumn{6}{|l|}{ TSH } \\
\hline Rendah & 8 & 38 & 5 & 55 & \multirow{3}{*}{$0,44^{*}$} \\
\hline Normal/tinggi & 13 & 62 & 4 & 45 & \\
\hline Total & 21 & 100 & 9 & 100 & \\
\hline
\end{tabular}

*uji Fisher Exact 
Tabel 4. Hasil analisis data sub grup

\begin{tabular}{|c|c|c|c|c|c|c|c|}
\hline \multirow{2}{*}{ Variabel } & \multicolumn{2}{|c|}{ Hidup } & \multicolumn{2}{|c|}{ Meninggal } & \multirow{2}{*}{ OR } & \multirow{2}{*}{ IK 95\% } & \multirow{2}{*}{$\mathrm{p}$} \\
\hline & $\mathrm{n}$ & $\%$ & $\mathrm{n}$ & $\%$ & & & \\
\hline \multicolumn{8}{|l|}{ T3 } \\
\hline Rendah & 21 & 95 & 7 & 87,5 & & & \multirow{3}{*}{$1,00^{*}$} \\
\hline Normal & 1 & 5 & 1 & 12,5 & & & \\
\hline Total & 22 & 100 & 8 & 100 & & & \\
\hline \multicolumn{8}{|l|}{$\mathrm{T} 4$} \\
\hline Rendah & 1 & 5 & 1 & 12.5 & & & \multirow{3}{*}{$0,26^{*}$} \\
\hline Normal/ tinggi & 21 & 95 & 7 & 87.5 & & & \\
\hline Total & 22 & 100 & 8 & 100 & & & \\
\hline \multicolumn{8}{|l|}{ TSH } \\
\hline Rendah & 7 & 31 & 6 & 75 & \multirow{3}{*}{0,156} & \multirow{3}{*}{$0,156(0,025-0,974)$} & \multirow{3}{*}{$0,049^{¥}$} \\
\hline Normal/tinggi & 15 & 69 & 2 & 25 & & & \\
\hline Total & 22 & 100 & 8 & 100 & & & \\
\hline
\end{tabular}

*Uji Fisher Exact

${ }^{¥}$ Uji. Pearson chi square

akan kembali normal. Berbagai perubahan tes fungsi kelenjar tiroid akan ditemukan pada berbagai macam penyakit sistemik, tanpa adanya bukti kelainan kelenjar tiroid. ${ }^{15-17}$ Penelitian mendapatkan penurunan kadar T3, dikuti dengan kenaikan T4, dan TSH. Perubahan ini pada aksis tiroid disebut euthyroid sick syndrome, low T3 syndrome atau non-thyroidal illness (NTI) syndrome. ${ }^{18}$ Sesuai dengan penelitian Brinker $\mathrm{dkk}^{19}$ yang mendapatkan 44 anak yang dirawat di PICU dengan kadar T3 rendah. Pada penderita dewasa, euthyroid sick syndrome dapat digunakan untuk memprediksi tingkat keparahan penyakit pada saat sakit berat. Pada populasi anak, belum ada data yang melaporkan perubahan hormon tiroid sebagai prediktor tingkat keparahan pada sakit berat. Joosten $\mathrm{dkk}^{13}$ melaporkan kadar T3 dan T4 lebih tinggi pada anak yang meninggal karena syok septik karena meningokokkus. Yildizdas $\mathrm{dkk}^{14}$ melaporkan kadar T3, T4, FT3, dan fT4 lebih rendah pada anak syok septik dibandingkan sepsis yang berhubungan dengan mortalitas pasien dengan sepsis, sementara penelitian terdahulu tidak menemukan adanya korelasi hormon tiroid dan kematian.

Pada penderita sepsis, dapat terjadi penurunan kadar T3 dalam sirkulasi beberapa jam selama fase akut. Penurunan kadar T3 ini bersamaan dengan kenaikan kadar T4 dan tanpa diikut kenaikan kadar TSH sebagai mekanisme kompensasi. Pada semua pasien dengan sakit berat, perubahan hormon tiroid ini akan selalu tampak sama sebagai respon adaptasi yang menguntungkan dan tanpa dilakukan intervensi. Euthyroid Sick Syndrome (ESS) ditemukan pada penelitian anak. ${ }^{10,13,14}$ Secara garis besar, peran ESS terbukti signifikan memainkan peran penting pada anak dalam berbagai kondisi. Hass $\mathrm{dkk}^{20}$ membedakan ESS menjadi 2 tipe ESS, tipe I dengan T3 rendah dikuti dengan T4 dan TSH normal, sedangkan tipe 2 T3 rendah diikuti T4 rendah. Euthyroid Sick Syndrome tipe 1 berhubungan dengan hasil yang baik dan ringan sampai sedang penyakit, ESS tipe 2 berhubungan dengan tingkat keparahan penyakit dan luaran yang buruk.

Didapatkan 1 subyek dengan kadar T3 normal, hasil kultur darah didapatkan kuman grup Salmonella $s p$ dengan kultur endotrakeal tube tidak didapatkan pertumbuhan kuman. Beberapa hal yang menyebabkan kadar T3 yang normal selama fase akut yaitu kemungkinan penurunan T3 terjadi pada awal infeksi (36-72) jam dan kembali normal setelah lebih dari 72 jam. Setelah 72 jam post infeksi TSH meningkat oleh karena hormon tiroid di perifer disekresi dengan mekanisme umpan balik maka kadar T3 kembali normal. Mekanisme ini disebut pemulihan aktivitas metabolik. $^{21}$

Brinker $\mathrm{dkk}^{19}$ yang melaporkan kadar T3 rendah yang dikuti dengan penurunan kadar TSH rendah berkorelasi positif dengan berat, lamanya sakit, dan luaran yang buruk. Subyek dengan kadar T3 
rendah dan diikuti kadar TSH rendah didapatkan luaran meninggal. Perubahan kadar T3 yang rendah apabila diikuti dengan kadar TSH yang rendah dapat digunakan sebagai nilai prognostik untuk kewaspadaan luaran pada anak sepsis. Angelousi $\mathrm{dkk}^{15}$ dalam sistemik review melaporkan beberapa penelitian yang mendukung penurunan kadar hormon tiroid pada awal sepsis mungkin terkait dengan hasil yang buruk pada pasien dengan sepsis atau syok septik. Meskipun temuan ini tidak konsisten, peran fungsi tiroid dalam memengaruhi atau hanya memprediksi hasil sepsis atau manfaat syok septik perlu investigasi lanjut.

Penelitian Peeters $\mathrm{dkk}^{22}$ yang menunjukkan penurunan kadar T3 dan kenaikan kadar rT3 berkorelasi dengan keparahan penyakit dan prognosis yang buruk dikaitkan dengan penurunan kadar T4. Berbeda dengan penelitian ini yang menunjukkan tidak terdapat perbedaan antara kadar hormon tiroid dengan kondisi sepsis baik perbaikan maupun perburukan. Pada penelitian Lodha $\mathrm{dkk}^{14}$ disimpulkan perubahan hormon tiroid bukan merupakan faktor penting yang berkontribusi pada keparahan syok septik dan mendapatkan perbedaan antara kadar hormon tiroid pada pasien sepsis dan syok septik. Pada anak, perbedaan kadar hormon tiroid dengan kondisi sepsis tidak didapatkan kemungkinan subyek yang diteliti tidak dibedakan antara sepsis dan syok septik dan pengambilan sampel tidak melihat lamanya perawatan sebelum sepsis.

Brinker $\mathrm{dkk}^{19}$ melaporkan perubahan kadar hormon tiroid pada penderita sepsis meningokokal dengan memperhitungkan derajat beratnya sepsis, kadar ratio antar rT3/T3, dan pemberian inotropik menyimpulkan perubahan kadar hormon tiroid dalam 24 jam pertama mempunyai nilai prognostik terhadap lamanya perawatan di PICU. Pada keadaan sepsis berat dan syok septik, keduanya didapatkan kadar fT4 dan TSH yang rendah karena penurunan plasma TBG T4 atau transthyretin yang akan menurunkan plasma tiroid binding capacity. ${ }^{22}$ Pada penelitian ini, semua subyek tidak dibedakan derajat beratnya sepsis, kadar hormon tiroid hanya diperiksa pada saat sepsis ditegakkan, dan tidak memperhitungkan ratio rT3/T3 dan pemberian inotropik. Dopamin mempunyai efek supresi terhadap sekresi TSH hipofisis dengan menghambat secara langsung fungsi hipofisis melalui reseptor dopamin inhibitor, berakibat sekresi TSH berkurang. Perubahan ini termasuk dalam kondisi sakit berat. ${ }^{14,18}$

Penelitian ini memiliki terbatasan penelitian, di antaranya peneliti tidak membedakan derajat sepsis, tidak menghitung ratio $\mathrm{T} 3 / \mathrm{rT} 3$, dan tidak memperhitungkan penggunaan inotropik

\section{Kesimpulan}

Tidak ada perbedaan yang signifikan kadar hormon tiroid dengan kondisi anak dan terjadi Euthyroid Sick Syndrom bila dikuti kadar TSH rendah terdapat kemungkinan terjadinya luaran yang buruk pada sepsis.

\section{Daftar pustaka}

1. Setiati TE, Soemantri AG. Patofisiologi dan penanganan sepsis. Sepsis dan disfungsi organ multipel pada anak patofisiologi dan penatalaksanaan. Semarang: Pelita Insani; 2009. h. 1 - 15 .

2. Chow A, Chan K. Management of septic shock: current consept. Hongkong J Pediatr 2003;8:3 - 14.

3. Nguyen HB, Rivers EP, Abrahamian FM, Moran GJ, Abraham E, Trzeciak S, dkk. Severe sepsis and septic shock: review of the literature and emergency department management guidelines. Ann Emerg Med 2006;48:2448.

4. Powel K. Sepsis and shock. Nelson textbook of pediatrics;2000.h.744 - 51 .

5. Proulx F, Fayon M, Farrell CA, Lacroix J, Gauthier M. Epidemiology of sepsis and multiple organ dysfunction syndrome in children. Chest 1996;109:1033 -7.

6. Fattah AC. Sepsis dan syok septik. Buku ajar ilmu kesehatan anak IDAI. Jakarta: IDAI;2002.h.391-8.

7. Landenberg PV, Shoenfeld Y. New approaches in the diagnosis of sepsis. IMAJ 2001;3:439 -41.

8. Latief A. Pendekatan diagnosis sepsis. Dalam: Lubis M, Evalina R, Irsa L, penyunting. Makalah lengkap Simposium Nasional Pediatri Gawat Darurat VI Bagian Ilmu Kesehatan Anak Medan. Medan: FK USU; 2003.h.28 - 35.

9. M Michalaki, A G Vagenakis, M Makri, F Kalfarentzos, Kyriazopoulou V. Dissociation of the early decline in serum T3 concentration and serum IL-6 rise and TNF alfa in non-thyroidal illness syndrome induced by abdominal surgery. J Clin Endocrinol Metab 2001;86:4198- 205.

10. Anand NK, Chandra V, Sinha RSK, Chellani H. Evaluation of thyroid functions in critically Ill infants. 
Indian Pediatric 1994;31:1233 - 37.

11. Chopra IJ. Euthyroid sick syndrome: is it a misnomer? J Clin Endocrinol Metab 1997;82:329-34.

12. Schuetz P, Muller B, Nusbaumer C, Wieland M, ChristCrain M. Circulating levels of GH predict mortality and complement prognostic scores in critically ill medical patients. European J Endocrinol 2009;160:157-63.

13. KFM Joosten, ED De Kleijn, M Westerterp, M De Hoog, FCV eijck, WC J Hop, dkk. Endocrine and metabolic responses in children with meningoccocal sepsis: striking differences between survivors and nonsurvivors. J Clin Endocrinol Metab 2000;85:3746 - 53.

14. Lodha R, Vivekanandhan S, Sarthi M, Arun S, Kabra $S$. Thyroid function in children with sepsis and septic shock. Acta Peadiatrica 2007;96:406 - 9.

15. AG Angelousi, DE Karageorgopoulos, AM Kapaskelis, Falagas M. Association between thyroid function tests at baseline and the outcome of patients with sepsis or septic shock: a systematic review. European J Endocrin 2011;164:147- 55 .

16. Aytug S. Euthyroid sick syndrome. (diakses 15 September 2014). Didapat dari:http://emedicine.medscape. com/article/118651-overview; 2006.

17. Maxime V, Siami S, Annane D. Metabolism modulators in sepsis: The abnormal pituitary response. Crit Care Med 2007;35:596-61.

18. Mebis L, Berghe Gvd. The hypothalamus-pituitary-thyroid axis in critical illness. Neth J Med 2009;67:332-40.

19. Brinker Md, Joosten KFM, Visser TJ, Wim C. J. Hop, Rijke YBd, Hazelzet JA, dkk. Euthyroid sick syndrome in meningococcal sepsis: the impact of peripheral thyroid hormone metabolism and binding proteins. J Clin Endocrinol Metab 2005;90:406-9.

20. Haas NA, Camphausen CK, Kececioglu D. Clinical review: thyroid hormone replacement in children after cardiac surgery--is it worth a try? Crit Care 2006;10:213.

21. Klein JR. The immune system as a regulator of tiroid hormon activity. Experimental Biology and Medicine 2009;321:229-36.

22. Peeters RP, Wouters PJ, Kaptein E, Toor Hv, Berghe GVd. Reduced activation and increased inactivation of thyroid hormone in tissues of critically Ill patients. J Clin Endocrinol \& Metab 2003;88:3202 -11. 